\title{
FORMULATING A PERFORMANCE MEASUREMENT SYSTEM USING BALANCED SCORE CARD IN ISLAMIC PHILANTHROPY INSTITUTIONS
}

\author{
A’ieshah Abdullah Sani*, Amilia Saidin, Khair Syakira Bustamam, Siti Azrina Adanan \& \\ Khairunnisa Abd Samad \\ Faculty of Accountancy, Universiti Teknologi MARA, KM26, Jalan Lendu, 78000 Alor Gajah Melaka
}

\begin{abstract}
The introduction of Balanced Score Card (BSC) as one of the management accounting tool to measure the performance of companies in both aspect of financial and non-financial position has been predominantly used since 1992 and had resulted positive energies for the profit making companies. Hence, the extension of the BSC is also required to help the social business organisation in delivering their multiple bottom lines in the most effective ways and provide organisations a mechanism to track their performance holistically through both quantitative and qualitative information. The growing of Islamic Philanthropy Institutions (IPI) especially in Malaysia with the objective to promote social development based on the charitable activities has been acknowledged by the society. Therefore, in order to ensure the sustainability of these institutions, a proper measurement system is required to ensure the final goal of the institutions is achievable and successful. Thus, the objective of this paper is to formulate the main indicators and variables that are suitable to measure the IPIs based on BSC system in four main perspectives which are financial perspective, stakeholder's perspective, internal process perspective and learning and growth perspective. The uniqueness of the establishment of IPIs would require different indicators and variables which are more appropriate as compared with the profit sector organisations. The outcome of this study could provide clear picture and guidelines in designing a proper performance measurement system to be implemented by current IPIs in Malaysia in order to maintain the sustainability and competitiveness of this institutions in future.
\end{abstract}

Keywords: Balanced Score Card, Islamic Philanthropy Institutions, Sustainability

\section{INTRODUCTION}

In recent years, the Islamic Philanthropy Institutions (IPIs) had been noticed for its existence in the current environment, especially in Malaysia. It is acknowledged by the society as a non-profit organization that promote social development based on charitable activities. Because of its ultimate goal for the society benefits, there is less concern on performance measurement especially on profit figures. However, with the increasing numbers of IPIs, people are questioning on the credibility and sustainability of this organizations in handling their resources as well as their activities. Alam (2010) in his study found that Muslims are less concerned about the use of their philanthropy, arguing that their responsibility ends with fulfillment of the obligation to give, and that charitable institution have to account for their use of funds. The rapid growth of IPIs with poor governance system would motivate the creation of proper system to be implemented in enhancing the quality of IPIs in Malaysia.

* Corresponding author's email: aieshah124@bdrmelaka.uitm.edu.my, Contact no: 012-2546914 
On the basis of non-profit organization, it is more accurate to measure the performance of IPIs using non-financial measures instead of solely focusing on financial measures. Thus, this paper will focus on formulating a performance measurement that are suitable to apply for social enterprises, particularly IPIs using a well-known management tool, which is Balanced Scorecard (BSC). Since the introduction of BSC by Kaplan and Norton (1992), it had emerged throughout the years in order to keep applicable with the changing economy and business environment. The BSC allows the management of non-profit organization to innovatively evaluate on a practical basis mixing the financial and non-financial perspective which ultimately creating a report for decision making process (Hartnett \& Matan, 2011). The four perspective measure identified are financial perspective, stakeholder's perspective, internal process perspective and learning and growth perspective. With the recent evolving BSC, it will further tied up the four perspective with the organization's strategic plan.

This conceptual paper will focus on existing literature of using BSC for performance measurement and reporting of social enterprise, particularly on IPIs and further propose a framework for IPIs in measuring their performance especially for sustainability purposes. The strength of BSC in strategy development will help the IPIs in meeting the organization's objective while delivering the best for the society.

\section{LITERATURE REVIEW}

\section{ISLAMIC PHILANTHROHY INSTITUTIONS}

The word of philanthropy is related with the noble work performed by an individual or a group of individual regardless either the contributions is being made to the other people, community or nation as a whole. In general, philanthropy can best be described as kind, pleasant, helpful, charity, voluntary, and aid work. Philanthropy can also be defined as contributions made by an individual or group in terms of time, money, labour, ideas and other things in a sincere manner without any compulsion and not expecting any rewards from the recipients (Muhammad Iqmal Hisham Kamaruddin \& Nathasa Mazna Ramli, 2015). Philanthropy activities being taught by all religion and in Islam, these activities are considered as part of the human action in lives as it is supported by several Quranic verse on voluntary acts such as from verse 2:280 mentioned that: "And if someone is in hardship, then [let there be] postponement until [a time of] ease. But if you give [from your right as] charity, then it is better for you, if you only knew."

The growing of philanthropy organization in Malaysia is mushrooming from year to year in order to cater for the social development and fulfil different needs of the society. Basically, there are various types of non-profit organizations including Islamic philanthropic organizations in Malaysia and it can be classified into four main categories, which are (1) societies; (2) associations; (3) foundations; and (4) companies limited by guarantee. Based on annual statistic by the registry of society (ROS), the application for registration of non-profit organizations with the ROS has increased tremendously from year 2013 until august 2016. This comprised from 12,777 applications in year 2013, 30,445 in year 2014, 30,071 in year 2015 and 27,704 registrations until august 2016. All the non-profit organizations registered with the ROS has been classified into ten categories which are; (1) political organizations; (2) welfare organizations; (3) social organizations; (4) recreation organizations; (5) arts and cultural organizations; (6) human right organizations; (7) trading organizations; (8) security 
organizations; (9) religious organizations; (10) professions organizations; and (11) other organizations (Registrar of Society, 2016).

Nowadays, the magnitude of philanthropic giving in Muslim societies is quite high either through obligatory form of charity which is zakat or any other various form of voluntary acts such as waqf (perpetual voluntary charitable act), infak (voluntary gift for restricted purpose) and sadaqah (voluntary charity either in monetary or non-monetary form). Thus, the growing of Islamic philanthropic institutions (IPIs) particularly in Malaysia is significant in managing all these resources efficiently with the main goal to achieve the social development and solve the community problems effectively. Basically, the existence of IPIs in Malaysia is regulated under state government such as state zakat department, state Islamic religious councils (SIRCs), waqf institutions, state Islamic religious schools, baitulmal and others. The main state institutions is 14 IPIs which represent each state in Malaysia, however there is also some of the private institutions to cater for Islamic philanthropy activities such as Awqaf Holdings Berhad, Waqaf An-Nur Corporation Berhad and others that registered as non-profit organizations with ROS. Therefore, a need of proper measurement system is required to ensure that all the resources in IPIs are being utilized and managed properly and efficiently so that the ultimate goal of upliftment the economy of the poor and reduce social inequalities is achievable.

\section{BALANCED SCORE CARD (BSC) MODEL IN IPIS}

IPIs need to start measuring their performances in a systemic way, in order to support decision making and ensure accountability towards their stakeholders. In order to be as effective and successful than profit-making organizations, IPIs need to be highly innovative in creating reporting practices and measurement systems because they are not as developed and extensive than the measurement systems for financial reporting of profit making companies. However, because of hybridity nature of IPIs, performance measurement and reporting processes are very complex and challenging for them. Thus, this paper is aiming to propose a proper balanced score card model that could be utilized by IPIs in measuring their performance to deliver its multiple bottom lines goals. Balanced score card is one of the most common management tools that enable organizations to consider both hard and soft sides of business (London \& Scorecard, n.d.).

The proposed framework of balanced score card that is suite with IPIs is based on the framework as adopted by non-profit organizations and social enterprises. According to Hartnett \& Matan (2011), the application of the BSC able to transform their organization's strategy, set measurable goals and design a timetable for execution. BSC is one of the tool that able to measure and observe the cause and effect relationships between the organizations key objectives and an accurate report on leading and lagging initiatives. Therefore, in order to ensure the effectiveness of BSC application for IPIs, the measurement of BSC must be designed in a holistic form covering all four main elements of BSC which are financial perspective, stakeholder perspective, internal process perspective and learning and growth perspective. 


\section{Financial perspective}

This perspective is important in order to measure the financial sustainability of the IPIs. BSC could help IPIs to identify the key drivers or ways of achieving success in financial perspectives by identifying what is the key stakeholders want from the organisation and what processes it needs to put in place internally to deliver things. IPIs must be well understanding of the institutions' financial health and able to utilize it efficiently to achieve the strategic goal. Some of the common measurement in financial area includes the measurement of operating income, return on capital, and economic value added (R. S. Kaplan, 2009). However, IPIs or non-profit organizations are not focussing on profit oriented. The BSC model would be customized to ensure that IPIs have available timely data on funding sources where part of it to cover its cost of services and other overhead costs. The management of IPIs must be well informed about the financial health of the organization and be comfortable with the financial statements and budgets. These financial reports is significant in providing a solid basis for operations and build confidence with funders, donors, grantors and other sources of revenue (Hartnett \& Matan, 2011).

\section{Stakeholder perspective}

This perspective is about the donor, volunteer or clientele experience, which is found by measuring satisfaction and retention as well as assessing the non-profit's market share in its position. Every non-profit should measure the attitude of its strongest and most loyal supporters to gain the most for the organization. Keeping donors and volunteers engaged and enthusiastic is required and through $\mathrm{BSC}$, it able to identify the main key drivers and performance indicators which could provide an incredible advantage for any organization (Somers, 2005). IPIs need to widen its stakeholder perspective by considering more on both side which are the donors and the recipients as well as the IPIs impact towards enhancing the community development as a whole. Similarly, as for profit oriented companies, Kaplan and Norton (2001) highlighted the core of business strategy is based on customer value proposition which describes the unique mix of product, price, service, and image that a company offers. According to Martello, Fischer \& Watson (2008), an organization must identify the right scope of customer attraction and its competitors in order to remain relevance in delivering to their customer's needs. The same principle also could be apply for IPIs whereby the satisfaction of recipients and donors is being measured appropriately to create value proposition.

\section{Internal Process Perspective}

This perspective involves measuring the cost, throughput and quality of the non-profit's key operational processes such as programs provided, services offered, and ability to address targeted recipient's needs. This internal focus gives a whole picture and a thorough understanding of how well the non-profit is running and can help them determine which programs and services are meeting the real needs of the community. Martello et al. (2008) indicate in improving internal processes, there should be a connection between the overall strategy and the improvements. There should also be a determination of how the strategy is to be measured. Typically, there are three main indicators fall under internal process which are cost related, time related and quality related (R. Kaplan, 2001). Hence, to measure the efficiency and effectiveness of the IPIs operation, it should include qualitative measurement in terms of process quality, cycle times and survey from public or recipients (Figge, Hahn,

* Corresponding author's email: aieshah124@bdrmelaka.uitm.edu.my, Contact no: 012-2546914 
Schaltegger \& Wagner, 2002). It is vital to assess the overall effect of each program in order to maintain the sustainability of IPIs and always relevance for the society.

\section{Learning and Growth Perspective}

Basically, this perspective looks at the non-profit's human capital which are its employees, volunteers and its board of directors in order to measure satisfaction, necessary skills, community connections, retention and adherence to the organization's mission. Since the staff and volunteers represent the organization's major resources, it is imperative that their performance is appropriately measured. Decisions on training and skill building can be based, in part, on their level of knowledge about the organization. The management of IPIs can also take into account the business skills needed to advance the mission, such as donor development, marketing and branding, leadership, communications and the use of technology to support every aspect of the organization (Martello et al., 2008). High performing boards, volunteers and staff are a prerequisite to the success of any non-profit (Zimmerman, 2009). The learning and growth perspective focuses on the creation of organizational value through employees and innovative practices. Nonfinancial metrics for this perspective may relate to employee turnover, employee cross-training and skill levels, and other product development indicators. Kaplan (2001) described that the learning and growth perspective involves a determination of employee capabilities and skills, technology, and a corporate climate needed to support a strategy. The human resources, technology and organizational climate must be aligned with the strategies within the other three perspectives giving the organization linkages among the four perspectives (Kaplan and Norton, 1996 b, 2001). 


\section{PROPOSED BSC MODEL FOR IPIS.}

The diagram below shows the proposed measurement variables using BSC for IPIs:

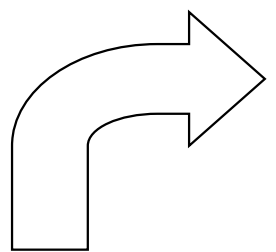

\section{Financial measurement}

- Percentage of funding sources

- Percentage of overhead costs (such as fundraising cost, service cost)

- Percentage of total fund allocated to the beneficiaries

\section{Learning \& Growth measurement}

- Percentage of staff having minimum competency requirements

- Employee satisfaction survey

- Number of value based training conducted by IPIs to their staff/employees

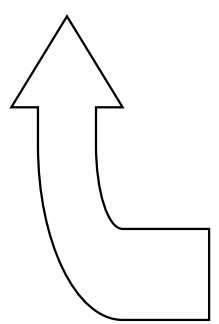

\section{Stakeholder measurement}

- Percentage of people who participate in philanthropy activities

- Percentage of people satisfied with the program conducted by IPIs

- Percentage of people who continuously employed by IPIs

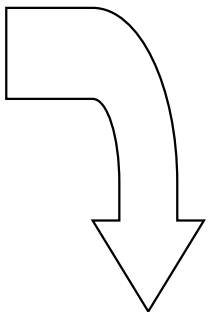

\section{Internal Process measurement}

- Percentage of people satisfied with the program

- Cycle time from collection to distribution

- Public survey/ feedback on IPIs

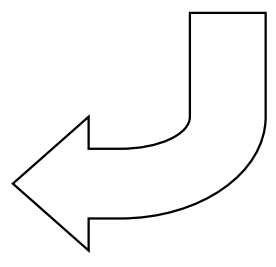




\section{CONCLUSION}

In conclusion, the proposed BSC model is useful in order to track the performance of IPIs holistically through both quantitative and qualitative information. BSC is primarily an internal management tool which draw cause and effect relationship between organization's strategies, vision and mission with appropriate measurement (Hoque, 2014). However, this study only propose the basic framework of BSC that could be applicable for IPIs. The realization of this framework can be utilized using actual case study research for IPIs in Malaysia. This lead to the limitation of this study whereby further research should be done to test whether the proposed measurement is suitable and practical for IPIs. Having good measurement system for IPIs is significant in order to ensure the sustainability of the institutions as well as improve the governance of IPIs. Thus, this study could provide clear picture and guidelines in designing a proper performance measurement system to be implemented by current IPIs in Malaysia in order to maintain the sustainability and competitiveness of this institutions in future.

\section{REFERENCES:}

Alam, N. (2010). Islamic Venture Philanthropy: A Tool for Sustainable Community Development. SSRN Electronic Journal, (March 2010), 1-14. http://doi.org/10.2139/ssrn.1565859

Figge, F., Hahn, T., Schaltegger, S., \& Wagner, M. (2002). The sustainability Balanced Scorecard - Theory and Application of a Tool for Value-Based Sustainability Management. Greening of Industry Network Conference 2002, Gothenburg, 1-32. http://doi.org/10.1002/bse.339

Hartnett, B., \& Matan, R. (2011). The Balanced Scorecard: A Strategic Tool for the Nonprofit Sector, 15. Retrieved from http://sobelcpa.com/sites/default/files/whitepaper.Jan2011 final.pdf

Hoque, Z. (2014). 20 years of studies on the balanced scorecard: Trends, accomplishments, gaps and opportunities for future research. British Accounting Review, 46(1), 33-59. http://doi.org/10.1016/j.bar.2013.10.003

Kaplan, R. and Norton, D. (1992). The Balanced Scorecard - Measures That Drive Performance.ll Harvard Business Review 70(1): 71-79.

Kaplan, R. (2001). Strategic Performance Measurement and Management in Nonprofit Organizations. Nonprofit Management \& Leadership, 3(Spring), $353-370$. http://doi.org/10.1002/nml.11308

Kaplan, R. S. (2009). Conceptual Foundations of the Balanced Scorecard. Handbooks of Management Accounting Research, 3, 1253-1269. http://doi.org/10.1016/S17513243(07)03003-9

London, S. E., \& Scorecard, B. (n.d.). Social Enterprise Balanced Scorecard. Chief Executive.

Martello, M., Fischer, M. J., \& Watson, J. G. (2008). Implementing a Balanced Scorecard in a Not-For-Profit Organization. Journal of Business \& Economics Research, 6(9), 67-80.

Muhammad Iqmal Hisham Kamaruddin, \& Nathasa Mazna Ramli. (2015). Enhancing financial accountability of Islamic philanthropic organizations through financial

* Corresponding author's email: aieshah124@bdrmelaka.uitm.edu.my, Contact no: 012-2546914 
disclosure. Online Journal Research in Islamic Studies, Volume 2 N(2015), 29-42. http://doi.org/10.15364/ris15-0201-03

Registry of Societies Malaysia (ROS) Website: http://www.ros.gov.my/index.php/en/semakan-pendaftaran, accessed on September 1, 2016.

Somers, A. B. (2005). Shaping the balanced scorecard for use in UK social enterprises. Social Enterprise Journal, 1(1), 43-56. http://doi.org/10.1108/17508610580000706

Zimmerman, J. (2009). Using a Balanced Scorecard in a Nonprofit Organization. Nonprofit World, 27(3), 10-12. http://doi.org/10.1108/13683040110397248 